\title{
Efficient Market Hypothesis and Fraud on the Market Theory A New Perspective for Class Actions
}

\author{
Franck Jovanovic, University of Leicester \\ Stelios Andreadakis, University of Leicester \\ Christophe Schinckus, University of Leicester
}

\begin{abstract}
Following recent judgement of the Supreme Court of US (June 2014), several commentators had declared that "Securities class actions are here to stay" (insidecounsel.com - September 2014, 11). This paper provides a critical perspective on this judgement, which "implicates substantive issues at the intersection of economic theory, financial markets, and securities regulation" (128 Harv. L. Rev. 291 2014-2015, 291), and shows that we must be much more careful. This recent judgement is based on the Fraud on the Market Doctrine, which was introduced in 1973 in order to preserve the class action procedure in securities fraud litigation. The characteristic of the Fraud on the Market Doctrine is to have been structured from one of the most popular financial theory: Efficient Market Hypothesis. In this paper, by analysing the implementation of the Efficient Market Hypothesis in Fraud on the Market Theory, we argue that if the Supreme Court had to take position for a second time about the Fraud on the Market Doctrine it is due to the practical difficulties inherited from Efficient Market Hypothesis and that have raised several problems to the US courts, including the Supreme Court. This issue is illustrated by the definition of Efficient Market Hypothesis lawyers used ("most" vs "all""'fully"). As this paper shows, if "Securities class actions are here to stay", the opportunity to open such a class action is strongly reduced in the facts.
\end{abstract}

\section{Introduction}

In June 2014, the Supreme Court of US provided a new judgment on the Fraud of the market theory. Several commentators had declared that "Securities class actions are here to stay" (insidecounsel.com - September 2014, 11). This paper provides a critical perspective on this judgement and shows that we must be much more careful. This article analyzes how the Efficient Market Theory, one of the most popular theories of financial economics, has been used in the development of Fraud on the Market Doctrine (also called Fraud on the Market Theory), a key legal doctrine in modern securities fraud litigation. How should courts deal with modern securities fraud, where a misleading misrepresentation can have a global impact on the market and affect investors who may not even be aware of the controversial statement? American courts have chosen to 
replace the individual reliance traditionally required in fraud lawsuits with the idea that the price of shares in an efficient market "reflects all publicly available information, and, hence, any material misrepresentation" (Erica P. John Fund v. Halliburton, 131 S. Ct. 2179 [2011]). Thus, under the Fraud on the Market Doctrine, courts may presume that an investor who buys or sells stocks at the market price did so on the strength of the public information that is the subject of the litigation. This idea was borrowed from financial economists, who formulated the Efficient Market Hypothesis in the 1960s.

In this article, we study how the Efficient Market Hypothesis has been introduced into American law through the Fraud on the Market Doctrine. The Efficient Market Hypothesis was one of the most important theories in the development of financial economics and is nowadays considered one of the main hypotheses underlying financial theories and models. Although the history of this theory and the circumstances that led to its creation is often ignored, it has been pointed out that it is polymorphous and that its empirical validity is controversial - particularly among financial economists themselves. Consequently, the theory is not so easy for jurists to use as might be imagined. In this article, we contrast the history of the Efficient Market Hypothesis in the discipline of financial economics with its reception in U.S. case law and the development of securities litigation since the 1970s. Then, we identify the major differences in the way the two fields understand and use market efficiency.

The first part studies how the Efficient Market Hypothesis has been progressively incorporated into the definition of Fraud on the Market Doctrine, through successive cases that were decided in the 1970s and the 1980s. It also follows its development through judicial reasoning in a series of more recent cases and attempts to justify its extensive use by the US courts and the rationale behind its application in securities fraud litigation. The second part emphasizes the polymorphous dimension of this theory and the fact that its practical application has never been demonstrated, while it also addresses the consequences of this polymorphism and how the U.S. courts have progressively created a completely different interpretation of this theory. Our analysis will shed some light on recent debates that have taken place before the Supreme Court about the criteria for applying Fraud on the Market Doctrine and the necessity of adopting a strict definition of an efficient market.

\section{The legal roots of the Fraud on the Market Doctrine}

The legal roots of the Fraud on the Market Doctrine can be traced back to the first attempts to safeguard financial markets as well as the interests of investors from fraud and manipulation. This first part analyzes how the Efficient Market Hypothesis has been progressively incorporated into the Fraud on the Market Doctrine. We first look back at the origins of U.S. legislation designed to protect investors against frauds on financial markets. We then trace the progressive 
creation of Fraud on the Market Doctrine and the role that Efficient Market Hypothesis has played in its development. Emphasis will be given to the seminal case of Basic and the subsequent case law up until the most recent Halliburton case.

\section{I.1) The legal origins of Fraud on the Market Doctrine}

Following the 1929 stock market crash, two ground-breaking pieces of legislation were introduced in an attempt to protect investors in the financial markets: the Securities Act of 1933 (c. $38 \S 1,48$ Stat. 74, codified at 15 U.C.S. 77a-77aa), the first major federal legislation regulating trade in securities, which focused on mandatory disclosure requirements and gave private plaintiffs new rights of action $^{1}$; and the Securities Exchange Act of 1934 (c. $404 \S 1$, 48 Stat. 881, codified at 15 U.C.S. 78a-78pp), governing the trading of securities on secondary markets, which created the Securities and Exchange Commission (SEC) as the public enforcer of federal securities law. Both statutes reflected the Congress' intention to safeguard the integrity of the US market and to restore the public confidence in this well-developed, but impersonal, market. Such powerful legislative response sent a clear message that the United States were putting strong emphasis on shareholders' rights through disclosure requirements, rights of action and remedies for recovery of losses caused to investors by fraudulent conduct (Duffy 2005, 623, Mahoney 2009, 331).

In 1942, under the rule-making authority conferred under section 10(b) of the 1934 Act, the SEC introduced Rule 10b-5 ("Employment of Manipulative and Deceptive Practices") in the Code of Federal Regulations (17 C.F.R. 240). This rule provides a scheme by which investors would sue for damages caused by deceit regarding stocks. The initial judicial interpretation of Rule 10b-5 was derived from the common law tort of fraud, and required plaintiffs (i.e. investors) to provide evidence of an intentional misstatement or omission of a material fact on which they had relied and which had been the proximate cause of their injury.

The reliance element requires the plaintiffs to prove that they relied on the misleading public statements of the defendants (the company's directors, the bank, the asset manager, etc.), which caused them to suffer a loss. Easy to establish in the context of face-to-face transactions, this reliance requirement proved much harder for plaintiffs to satisfy in the context of mass impersonal transactions, such as those carried out in developed securities markets. ${ }^{2}$ Were the reliance requirement to be strictly construed, it would require a practically impossible investigation into the individual state of mind of several thousand

\footnotetext{
${ }^{1}$ The Act requires that investors receive financial and other significant information concerning securities being offered for public sale; and prohibits deceit, misrepresentations, and other fraud in the sale of securities.

${ }^{2}$ See 17 CFR § 240 10b-5; Stoneridge Investment Partners LLC v Scientific Atlanta Inc (2008) 128 S. Ct. 761 at 769; Dura Pharm Inc v Broudo (2005) 125 S. Ct. 1627 at 1631.
} 
members of the class - thus barring all securities fraud litigation from being the vehicle of access to justice that class action was initially designed to be.

Class actions gain their legitimacy from principles of judicial economy and efficiency, so a class action that does not ensure efficiency is by definition problematic (Gordon 2013). According to Rule 23 of the Federal Rules of Civil Procedure, a class action is permitted, if 'the court finds that the questions of law or fact common to the members of the class predominate over any questions affecting only individual members, and that a class action is superior to other available methods for the fair and efficient adjudication of the controversy' (Fed. R. Civ. P. 23 (b)(3)). This requirement that common issues 'predominate' over individual issues is extremely important, because '[r]equiring proof of individualized reliance from each member of the proposed plaintiff class effectively would [prevent named plaintiffs] from proceeding with a class action, since individual issues then would ... overwhelm [...] the common ones' (Basic, 231).

The Fraud on the Market Doctrine emerged in the late 1960s as a judicial response to these difficulties attached to claims arising from Rule 10b-5. Under this Doctrine, the plaintiff's reliance on the defendant's misstatements may be legally presumed where the relevant market is proved to be efficient. The Doctrine builds on arguments from financial economics, according to which in an efficient market, public information is reflected in the market prices of shares and conveyed to investors in this form; consequently, a person relying on the integrity of the market price can be said to rely indirectly on the public information it contains. This is why plaintiffs were using economists as expert witnesses, their reports and testimony in court in order to establish the efficiency of the market in question.

As it will be shown, the Theory has undergone a long evolution process, from a mere relaxation of the traditional reliance requirement in securities transactions to its emergence as a definite doctrine based on financial economics and technical standards. It first appeared as 'the artificially inflated market price theory' in the late 1960s but it was in 1972 that the Supreme Court, without yet making an explicit reference to the Theory, accepted that a positive proof of reliance was not required in cases of an omission of material facts by a party with a duty to disclose, and that plaintiffs should recover as damages the difference between the fair value the seller received for his shares and the fair value he would have received had there been no fraudulent conduct (Affiliated Ute Citizens of Utah v. United States, 406 U.S. 128 [1972]; "The fraud market theory" 1982, 1146; (Duffy 2005).

The Fraud on the Market Doctrine was then expressly introduced in 1973 by the District Court of California in the case of In re Consolidated Memory Cases (61 F.R.D. 88 [1973]), which favoured an objective standard of reliance that focuses 
on the "causal nexus" between the misinformation and the inflated price, in order to avoid the problem of showing the subjective intent of each investor in an action involving potentially 60,000 investors. In the context of a stock exchange, the sufficient assessment of reliance aims to determine whether a reasonable investor would have relied on the alleged misrepresentation. This objective standard of reliance was said to preserve the class action procedure in securities fraud litigation without altering defendants' substantive rights. A similar reasoning was adopted in Tucker v. Andersen (67 F.R.D. 468 [1975]), where the court asserted that the introduction of this new kind of proof was not revolutionary, but merely a derivative reliance element, and that the individual reliance which prevailed before was not free from criticisms. Indeed, in these same years, legal scholars and practitioners were stressing the necessary adaptation of fraud claims (American College of Trial Lawyers 1972, Simon 1972).

As it becomes apparent, in none of these cases so far was Fraud on the Market Doctrine explicitly associated with concepts drawn from financial economics. Posner in 1975 shared the belief that economics held the interdisciplinary key that would unlock the secret to a perfectly functioning legal system and explain the breakdowns in less than perfectly functioning legal systems (Posner 1975, 763-764) $)^{3}$. However, the Doctrine was applied in such a way that it was 'closer to civil procedure than financial economics' (Langevoort 2009, 158).

It was not before 1980 and the case of In re LTV Securities Litigation (88 F.R.D. 134 [1980]) that the Fraud on the Market was clearly anchored in theoretical reasoning of financial economics. According to the federal court's judgment, for a finding of reliance, it was sufficient to show that the plaintiff relied on the integrity of the market price of the share, which was distorted by the alleged misstatement of the defendant. The court revealed the market's role as a "transmission belt" linking the available information on stocks and individual purchasers and sellers:

With recent advances in the understanding of the economics of securities markets, it has become more demonstrable that reliance on the market price is conceptually indistinguishable from reliance upon representations made in face-to-face transactions (LTV Securities, at 142).

The court referred directly to the viewpoints of financial economists to justify the introduction of this presumption in the court system. In this judicial reasoning, the Efficient Market Hypothesis was invoked as an additional justification for the already existing doctrine of Fraud on the Market, thereby strengthening the case for class actions in securities fraud litigation. In this perspective, the Efficient

\footnotetext{
${ }^{3}$ It is worth mentioning that Efficient market hypothesis did not only influence the legal system ; it also has been used as a framework in the computerization of financial markets (Schinckus 2008) but also in the international standardization of accounting conventions (Chane-Alune 2006, Miburn 2008), the legal policies in US (Hammer and Groeber 2007) and financial regulators (Muniesa 2003, Pardo-Guerra 2015).
} 
Market Hypothesis is used for demonstrating that every fraudulent misrepresentation was necessarily reflected in stock prices, and that every investor could rely solely on those prices for transacting. Courts were therefore justified in relinquishing the requirement of direct reliance on the alleged misrepresentation whenever public information could have an automatic influence on prices. In LTV Securities, the court built on the concept of efficient market as it was directly borrowed from financial economics, quoting the economist Van Horne:

\begin{abstract}
Basically, efficient capital markets exist when security prices reflect all available public information about the economy, about financial markets, and about the specific company involved. Implied is that market price of individual securities adjusts very rapidly to new information. As a result, security prices are said to fluctuate randomly about their "intrinsic" values. To be sure, new information can result in a change in the "intrinsic" value of a stock, but subsequent stock price movements will follow what is known as a random walk. (LTV Securities at 144, citing Van Horne $(1977,45)$ )
\end{abstract}

If there is a case that can be characterised as an endorsement of the use of financial economics in security fraud litigation, then this is the case of Basic, as the Fraud on the Market Theory as a basis for imposing liability on defendants is firmly grounded on well proven notions in financial economics about market efficiency.

\title{
I.2) From Basic to Halliburton and beyond: The Jurists' Approach
}

The judgment in Basic has been considered as a turning point in the history of securities litigation. In an attempt to help investors overcome the abovementioned difficulties with the reliance requirement, the Court, with a rather unusual majority of four Justices, created a presumption that investors in securities fraud cases may be presumed to rely on public misrepresentations about stock trading, as the price of stock traded in an efficient market will reflect all public, material information, including misrepresentations (Basic, 991). The presumption is based on the ability of the plaintiffs to show that public, material misstatements were in fact made and thus, presumably affected the stock's price without having to prove that the investment decision in question was made based on these alleged misstatements (Carlson 2015).

According to the Supreme Court's reasoning, which followed the interpretation set out in LTV, 'the fraud on the market theory is based on the hypothesis that, in an open and developed securities market, the price of a company's stock is determined by the available material information regarding the company and its business ... Misleading statements will therefore defraud purchasers of stock even if the purchasers do not directly rely on the misstatements ... The causal connection between the defendants' fraud and the plaintiffs' purchase of stock in such a case is no less significant than in a case of direct reliance on misrepresentations' (Basic, at 242). The Supreme Court saw this Theory as a 'practical resolution to the problem of balancing the substantive requirement of proof of reliance in securities cases against the procedural requisites of [Federal 
Rule of Civil Procedure] 23 (Gordon 2013, 510).

Two phrases in the ruling in Basic encapsulate the jurists' approach towards the Efficient Market Theory. The Justices did not undertake the task to 'assess the general validity of the theory ...' (Basic, 242); they were obviously more concerned with its effectiveness and application in practice rather than its theoretical underpinnings. Secondly, they recognised the evolution and transformation of the modern securities markets and that it was prudent to define and apply the concepts of reliance and causation in a different way compared to the early fraud cases (Basic, 243-44; LTV Securities 143). After all, 'presumptions typically serve to assist courts in managing circumstances in which direct proof, for one reason or another, is rendered difficult' (Basic, 245).

This particular presumption was created in order to help judges in overcoming 'an unnecessarily unrealistic evidentiary burden on the Rule 10b-5 plaintiff who has traded on an impersonal market' (Basic, 245). It was a practical solution to successfully bridge the gap between theory and practice. In theory, '[a]ny showing that severs the link between the alleged misrepresentation and either the price received (or paid) by the plaintiff or his decision to trade at a fair market price will be sufficient to rebut the presumption of reliance' (Basic, 248). However, in practice it was almost impossible for defendants to successfully rebut the presumption (Weiss and Beckerman 1995, 2077). Milton Friedman argued in 1953 that "[T]he relevant question to ask about the "assumptions" of a theory is not whether they are descriptively "realistic," for they never are, but whether they are sufficiently good approximations for the purpose in hand. And this question can be answered only by seeing whether the theory works, which means whether it yields sufficiently accurate predictions.' (Friedman 1953).

The dissenting minority warned that "with no staff economists, no experts schooled in the 'efficient-capital-market hypothesis,' no ability to test the validity of empirical market studies, we are not well equipped to embrace novel constructions of a statute based on contemporary microeconomic theory" (Basic, 253). In other words, courts should prove the efficiency of the market by themselves, independently of tests provided by financial economists undertaking "a long journey without a particularly good compass." (Langevoort 2009, 167).

Fuller observes that '[s]ome rebuttable presumptions have, in the course of time, gathered about them rules declaring what is sufficient to overcome them. So soon as you have begun to limit and classify those things which will rebut a presumption you are importing into the facts "an arbitrary effect" beyond their natural tendency to produce belief' (Fuller 1930-31, 394). There were even 'empirical studies [that] have tended to confirm the premise that the market price of shares traded on well developed markets reflects all publicly available information, and, hence, any material misrepresentations. It has been noted that 
'it is hard to imagine that there ever is a buyer or seller who does not rely on market integrity. Who would knowingly roll the dice in a crooked crap game?' (Basic, 247).

When the Court stated that 'in an open and developed securities market, the price of a company's stock is determined by the available material information regarding the company and its business', it was wading into an economic swamp many decades in the making. Beginning in the late nineteenth century, stock market gurus postulated that the value assigned to corporate shares in an open market reflects all information available about them (Fox 2010, xiii). This mind-set soon crystallised into a theory, the rational market theory, which built from the observation that stock prices move randomly ('random walk'), to the claim that one cannot predict stock prices based on public information, and on to the conclusion that stock prices are fundamentally correct (Fox 2010, xiv).

The period between 1987 and 2014 can be characterised as the period of reign for Basic. In 2014 the Supreme Court was faced with the challenge of having to confront its own creation. It was not the first time that the ruling in Basic was under attack. Starting from Amgen $v$ Connecticut Retirement Plans, where Justices Alito and Scalia were extremely pessimistic about the fate of the Efficient Market Hypothesis and talked about the consequences of the theory as becoming from 'arguably regrettable' to 'unquestionably disastrous' (Amgen, 1204-6), the Theory has been criticised as 'naïve', 'simplistic', 'outdated', in need of scrutiny, repudiated by empirical economics studies and also inconsistent with the Court's jurisprudence in Wal-Mart $v$ Dukes and Comcast $v$ Behrend ${ }^{4}$. Perhaps the biggest concern had to do with the realisation that markets are not as efficient as anticipated and stock prices in an efficient market cannot possibly reflect all publicly available information immediately.

Another important problematic issue comes to the surface if we examine carefully the cases before and after Basic. Basic established that the plaintiffs in a Rule 10b-5 action must, in order to avail themselves of the Fraud on the Market presumption, prove that the stock market in which they transacted was efficient. Since the Supreme Court provided no definition of what makes a market efficient for legal purposes, this became the next hot topic in securities fraud cases. The first significant decision regarding the definition of the efficient market, Cammer v. Bloom (711 F. Supp. 1264 [1989]), gave a very realistic definition of what should qualify, in law, as an efficient market. 'An efficient market is one which rapidly and accurately reflects new information in price'. (Cammer, $711 \mathrm{~F}$. Supp.

\footnotetext{
4 'Under Basic, putative plaintiff classes bringing Rule 10b-5 claims are given special solicitude available to no one else - immunity from the very Rule 23 principles articulated in cases like WalMart and Comcast'. 'At the very least, Basic's outdated economic theory should undergo the searching scrutiny given to the methodologies proffered to establish predominance in Wal-Mart and Comcast'.
} 
1264 at 1276, quoting Bromberg and Lowenfels (1988)) Therefore, Cammer can be seen as an attempt to transpose the economic concept of efficient market into very pragmatic considerations.

Subsequently, in 2004, in a judgment that was overturned by the Court of Appeal in 2005, Justice Keeton had refused to rely on a strict economic definition of an efficient market: an "efficient" market in the context of the "Fraud on the Market" theory is not one in which a stock price rapidly reflects all publicly available material information. Rather, the "efficient" market required for "Fraud on the Market" presumption of reliance is simply one in which "market professionals generally consider most publicly announced material statements about companies, thereby affecting stock market prices". (In re PolyMedica Securities Litigation, 224 F.R.D. 27 [2004] at 41, citing Basic, 485 U.S. at 246).

Justice Keeton justified this definition by stressing the distinction between the theoretical definition provided by economists and the practical considerations necessary in legal proceedings, and reiterated the cautions of the Supreme Court in Basic: ... the Court emphasized that no strict economic theory need be adopted by adjudication: "We do not intend conclusively to adopt any particular theory of how quickly and completely publicly available information is reflected in market price." (PolyMedica (2004), 224 F.R.D. at 40-41, citing Basic, 485 U.S. at 249)

The defendant appealed the decision, alleging an error of law in the interpretation of market efficiency, and the Court of Appeal of the First Circuit reversed the decision in 2005. By rejecting the prevailing definition of market efficiency advocated by PolyMedica and focusing instead on the general consideration by market professionals of most publicly announced material statements about companies, the district court applied the wrong standard of efficiency. For application of the fraud-on-the-market theory, we conclude that an efficient market is one in which the market price of the stock fully reflects all publicly available information (PolyMedica (2005), 432 F.3d at 14).

The debate in PolyMedica between the district court and the First Circuit court about the most suitable definition of market efficiency illustrates the difficulty of adopting concepts imported from financial economics to fit into the purposes of the legal system. A crucial factor was also the Supreme Court's reluctance to define efficiency. This is how we arrived at the two most recent Supreme Court judgments on Fraud on the Market, Erica P. John Fund v. Halliburton (131 S. Ct. 2179 [2011]) [Halliburton I] and Halliburton Co. v. Erica P. John Fund, Inc., 134 S. Ct. 2398 (2014) [Halliburton II]

The Supreme Court has had numerous opportunities during this period of more than 25 years to overrule Basic and challenge the Fraud on the Market Theory, but this never happened. No doubt that the rebuttal of the efficient-market 
presumption would be another cornerstone in the area of securities fraud litigation. The Halliburton saga can be seen not as another opportunity, but as the golden opportunity for the Supreme Court to rebut the Basic presumption. Instead the Court held that the presumption of reliance on misrepresentations cannot be rebutted at the class certification stage with evidence of a lack of price impact. Defendants were only to be permitted to provide evidence of such lack of price impact at the class certification stage, instead of the merits stage. '[A]n indirect proxy [such as the Basic presumption] should not preclude direct evidence when such evidence is available; price impact is ... an essential precondition for any Rule 10b-5 class action', but, according to Justice Thomas, the fraud-on-the-market presumption is 'virtually irrebuttable in practice' (Halliburton II, 2420 (Thomas J concurring). The decision in Halliburton II sent a clear message and preserved a crucial doctrine clearly favouring securities class action plaintiffs; adopting such approach it was revealed that the Court still values the role of the plaintiffs' bar (Carlson 2015, 169).

More specifically, it was held that requiring plaintiffs to prove price's impact as a means to rebut the Basic presumption is inconsistent with the presumption itself and it would 'radically alter the required showing for the reliance element of the Rule 10b-5 cause of action'. In fact 'it makes no sense, and can readily lead to bizarre results' (Halliburton II, 2414). The Court drew a clear line distinguishing proof of price from proof of materiality, as price impact is a key feature in the Basic construction. Fraud on the market was seen simply as an alternative means of satisfying reliance, an existing element of a claim. As a result, the reasoning did not alter the elements of the Rule 10b-5 cause of action and thus maintained the action's original legal scope (Brown 2015, 2-34.2). The dissenting Justices (Scalia, Alito and Thomas) questioned the accuracy of the fraud on the market theory and were against the imposition of such a broad theory by judicial fiat (Halliburton II, 2427 (Thomas J concurring).

The doctrine of fraud on the market is kept alive and shareholders in an efficient market are presumed to have relied on the integrity of the market price in making their investment decisions. However, the presumption of reliance can be rebutted at the class certification stage, provided that it can be proved that the alleged misrepresentation did not cause any distortion to the market price. This does not undermine the validity of the efficient market hypothesis or the extent to which the capital markets are fundamentally efficient. It just serves as a confirmation that there is no convincing evidence that the economic reality justifies the overruling of the Basic presumption. The Court performed a sensitive balancing exercise before deciding to preserve more than 25 years of established precedent as well as the ability of private parties to bring securities fraud actions. Class actions were not eliminated, but as a counterbalance companies were allowed to use event studies to challenge whether an allegedly fraudulent statement had in fact been absorbed by the market (see Local 703, I.B. of T. Grocery \& Food Emps. Welfare Fund v Regions Fin. Corp., 762 F.3d 1248, 1259 
$\left(11^{\text {th }}\right.$ Cir. 2014) It is not a ground-breaking decision, rather a sensible one, as it does not change the status quo in the field of securities litigation and reflects an attempt to deal with the concerns about the existing inconsistencies in the context of class certification proceedings.

The Justices, although not explicitly, supported the idea that at the end of the day it is the Congress, not the Supreme Court, that should decide and initiate such a reform in the securities class action rules. More specifically, it was acknowledged that the Congress has repeatedly enacted legislation to govern Rule 10b-5 litigation instead of disturbing the Basic presumption, for instance the Private Securities Litigation Reform Act 1995 and the Securities Litigation Uniform Standards Act 1998 (Harv LR, vol 128: 291, 297-8). The same argument had been made by Justice Kagan in Amgen, where he underlined the relevance of congressional acquiescence: in order to reverse a case, there must be something 'fundamentally different' today than when the case was decided, that is 'especially so....where the Congress has had every opportunity, and has declined every opportunity to change Basic' $(1184,1201)$.

Overall, the Court took a pragmatic stance towards the fraud on the market presumption and the policy implications of overruling Basic. Without this presumption, plaintiffs will not be able to prove class-wide reliance on misstatements; if plaintiffs cannot prove reliance, then they will be unable to satisfy the predominance requirement for class certification. As a result, individual plaintiffs, in absence of class classification, would have to sustain huge costs for bringing a claim (Rubenstein 2001, 392).

Having examined the development of the Efficient Market Hypothesis and the application of the Fraud on the Market Theory through the case law of the US courts, the next section will focus on the practical implications of the EMH from an economic viewpoint as well as the terminological issues and definitional problems that have arisen.

\section{Influence of the Efficient Market Hypothesis on Fraud on the Market Theory debates}

As we mentioned earlier, under the current understanding of the Fraud on the Market Theory, a demonstration of market efficiency by the plaintiff will open the door to a class action procedure. A securities fraud case will therefore typically involve a debate around whether or not the market, in which the securities were traded was efficient, with the plaintiffs (investors) trying to demonstrate this efficiency and the defendants (generally officers of the company) trying to disprove it. 
The main problem with this approach lies in the polymorphous definition of market efficiency. As we will explain in this part, jurists base their arguments on the Efficient Market Hypothesis, but they understand and use this hypothesis very differently from the way that financial economists have formulated it, and view it. In this part, we first explain the way financial economists created this hypothesis. Second, we highlight that, while economists and jurists use the same vocabulary, they do not attach the same meaning to the concepts used. Third, we show that the consequences of this cleavage are not only theoretical, but also practical, and that a too formalistic legal understanding of market efficiency tends to lessen investors' protection, as illustrated in the PolyMedica case.

\section{II.1. Efficient Market Hypothesis and its practical implication from an economic viewpoint}

The Efficient Market Hypothesis, which was created during the 1960s and the 1970s, asserts that financial markets are "informationally efficient" (Jovanovic $2008,2010)$. It suggests that stock prices reflect all available information, and that, consequently, a security's current price is equal to its intrinsic value (also called fundamental value). In addition, because new information arrives randomly, stock prices fluctuate randomly. While the consequence of the fact that stock prices reflect all available information (i.e. the actual price of a security is equal to its intrinsic value) is constitutive of the Efficient Market Hypothesis, courts have mainly focused on the first aspect of the theory only (that an efficient market means that all available information is reflected in prices), ignoring its second aspect (that price is equal to the fundamental value), which was the primary reason for the theory's creation by financial economists.

The definition of an efficient market that is generally used nowadays comes from Fama's 1970 article: "a market in which prices always 'fully reflect' available information is called 'efficient" $(1970,383)$. It is the definition on which courts based their own definitions of the Efficient Market Hypothesis in Cammer (1989) and Basic (1988) cases; it is also the definition adopted in Polymedica (2005) case. Although this definition is often quoted, in particular by economists, it has created many theoretical and practical difficulties. In 1976, the economist LeRoy ()()()() showed that Fama's 1970 demonstration is tautological and that his hypothesis is not testable. The effect of Fama's (1976) response was to modify a bit his definition. The new definition supposed that investors know the "true" model for pricing securities at their equilibrium values. The major consequence of this change was to admit that any test of the Efficient Market Hypothesis is a test of both market efficiency (i.e. prices correctly reflect all available information) and the model of equilibrium used by investors for evaluating the equilibrium price of securities (i.e. the fundamental or intrinsic value). Therefore, in the event of negative results for an empirical test of Efficient Market Hypothesis, we can either consider that the Efficient Market Hypothesis (i.e. the prices reflect all 
available information) has been refuted (although the model of equilibrium is the right one) or, more importantly, that the model used has been refuted (although the market is efficient). Financial economists call this problem "joint hypothesis," stating that, first, the market is efficient in equating asset prices with their intrinsic values; and second, that since we know what the intrinsic values are, we have a perfect asset pricing model. In this regard, whenever an empirical test rejects the hypothesis of an efficient market, we cannot know which part of this joint hypothesis (the Efficient Market Hypothesis or the model used to evaluate the assets) failed to work. In other terms, due to the joint hypothesis' problem, Efficient Market Hypothesis loses a large part of his practical implications.

\section{II.2. "Efficient market": one concept, several meanings}

Beyond the practical implications of the Efficient Market Hypothesis, the definition of this hypothesis has raised many problems. First of all, we must clarify that jurists and economists both use the term "efficient market," which would suggest that they understand the term in a similar way. The impression is strengthened by the explicit references to economic literature made by jurists. However, since the introduction of the Fraud on the Market Theory, crucial differences have crept into economists' and jurists' interpretation of what an efficient market is. A comparison between the way courts have used this concept to support the Fraud on the Market Theory and the way financial economists built this concept will enable us to point out two key differences in interpretation. The first concerns the use of the fundamental value, and the second, the kind of information reflected in prices.

\section{2.a) The use of the fundamental value}

The first difference pertains to the use of the fundamental value. It has long been acknowledged that jurists face a dual definition of market efficiency, depending on the importance given to the notion of fundamental value. Fischel, in 1989, had already distinguished between a "trading-rule efficiency" and a "value efficiency":

Much of the discussion of efficient capital markets suffers from ambiguity concerning what characteristics capital markets must satisfy to be considered "efficient." At least two definitions of "efficient" capital markets exist. The first [...] focuses on the speed with which market prices reflect publicly-available information and whether the price reaction to new information is without bias. Under this definition, a market is efficient if it is impossible to devise a trading rule that systematically outperforms the markets [...]. I refer to this definition as "trading-rule efficiency." [...]

The second definition of efficient capital markets focuses on the extent to which security prices reflect the present value of the net cash flows generated by a firm's assets. I refer to this definition of efficiency as "value efficiency" (Fischel 1989, 912-13). 
While this distinction between these two efficiencies ${ }^{5}$ is very common amongst jurists nowadays, it was not clear at the time the U.S. Supreme Court decided Basic (see Fisher 2005, 852), the fundamental case for the Fraud on the Market Theory (see part 1). The dissenting judges in Basic were indeed critical of Fraud on the Market Theory because, as J. White wrote, "it implicitly suggests that stocks have some "true value" that is measurable by a standard other than their market price." (Basic, at 255) In commenting on this assertion, Fischel relied on this distinction between two kinds of efficiency:

These points are correct but have nothing to do with the Fraud on the Market theory. Theory does not posit that there is some "true value" of an asset other than its price. On the contrary, theory assumes that market price is the best indicia of value which makes it all the more important that price not be distorted by fraudulent information (Fischel 1989, 920).

For Fischel, who was among the first to make such a distinction between "trading-rule efficiency" and "value efficiency", the former is associated with the Fraud on the Market Theory in the following reasoning:

The link between the concept of efficient capital markets and the Fraud on the Market theory is clear. The central premise of the Fraud on the Market theory is that prices of actively-traded securities reflect publicly-available information. The premise is roughly equivalent to the semi-strong version of efficient capital markets hypothesis." (Fischel 1989, 911)

By focusing on the public availability of information and on changes in stock market prices, jurists consider that their definition of market efficiency ("tradingrule" or "mechanical efficiency") can dispense with the issue of fundamental value. Such reasoning, however, is based on an erroneous reverse causality. Indeed, from the observation that both the legal doctrine of Fraud on the Market and the financial economic theory of efficient market posit the perfect integration of all publicly available information into financial prices, it is wrong to conclude that Fraud on the Market Theory logically involves the Efficient Market Hypothesis $^{6}$.

\footnotetext{
${ }^{5}$ The terms used to describe these two definitions of efficient market can vary from one author to another. For instance, Fisher (2005) used the terms "Mechanical efficiency" and "Value efficiency".

${ }^{6}$ Such reasoning confuses sufficient condition with necessary condition by the following logic:

1) Fraud on the Market Theory means that prices are affected by the dissemination of false information: therefore Fraud on the Market Theory $(F)$ implies financial prices perfectly reflect all publicly available information $(I)$

$$
F \rightarrow I
$$

2) since Efficient Market Hypothesis in its semi-strong version means that all publicly available information is reflected in financial prices $E M T \rightarrow I$
}

3) then Fraud on the Market Theory logically involves the EMT in its semi-strong version.

$$
F \rightarrow E M T
$$


The logical association of the Efficient Market Hypothesis with the Fraud on the Market Theory presupposes implicitly that all publicly available information being perfectly reflected in financial prices $(I)$ is a necessary condition for evoking the Efficient Market Hypothesis (EMH). In that case, EMH and I would logically be reciprocal and one could not be invoked without the other. ${ }^{7}$ However, this reciprocity does not exist in reality. Perfect reflection of publicly available information in prices is a condition for evoking the Efficient Market Hypothesis, but it is not enough because, as recalled previously, the Efficient Market Hypothesis also implies that people use the "true model" to value financial prices. In this respect, the Efficient Market Hypothesis requires the correct reflection of publicly information into financial prices, which must be equal to the fundamental value of assets. Consequently, breaking the link between price and the fundamental value destroys the raison d'être of the Efficient Market Hypothesis.

According to the Fraud on the Market Theory as widely propounded, financial prices do not necessarily reflect the fundamental value. For instance, in a passage quoted previously, Fischel explicitly wrote: "The [Fraud on the Market] theory does not posit that there is some 'true value' of an asset other than its price" (Fischel 1989, 920). In this view, publicly available information must be reflected in price, but there is no prescription as to the model of equilibrium used by agents and, consequently, we are no longer concerned with fundamental value. This shift explains why, for the courts, a demonstration of the existence of fundamental value is not considered decisive in order to prove market efficiency (in the legal sense) (None 2006, 2286). More specifically, jurists use an informational efficiency in which the process related to the evolution of financial prices is more important than the evidence of a potential fundamental value for each asset. In other words, jurists are more interested in the way prices react to information than in the existence of an intrinsic value for these prices. In this juridical perspective, it is possible to use the efficient market hypothesis without considering the necessity to have an economic benchmark.

This reasoning confuses sufficient condition and necessary condition. In the implication $F \rightarrow I, I$ is a sufficient condition to have $F$ - meaning that if $I$ is true, then this is adequate grounds to conclude that $F$ is true. Fraud on the Market Theory can be evoked when publicly available information is supposed to be integrated into financial prices. In the same vein, $l$ is also a sufficient condition to evoke the semi-strong version of EMT. However, even though $I$ is a sufficient condition for $F$ and EMT, we cannot deduce any relationship between these two statements. Indeed, to put it in more familiar words, if the floor is wet when the weather is rainy (Rain $\rightarrow$ Wet Floor), and if the floor is also wet when I spray it (Spray $\rightarrow$ Wet Floor) deducting that I spray when it rains (Rain $\rightarrow$ Spray) is a wrong reasoning.

${ }^{7}$ With the reciprocal implication, we can deduce one statement from the other. If the floor is wet when it rains (Rain $\rightarrow$ Wet Floor) and if the floor is wet when water is spilled (Spilled water $\leftrightarrow$ Wet Floor) then we can deduce that if it rains then we have a spilled water situation (Rain $\rightarrow$ Spilling Water) because we have a logical reciprocity between the statements Wet Floor and Spilled Water. 
Although the distinction between "trading-rule efficiency" (or "mechanical efficiency") and "value efficiency" seems to meet the concerns of jurists, from an economic viewpoint, this distinction highlights a crucial question about the referent chosen. Assessing whether the price reaction to new information is without bias requires a referent. In 1965, when Fama built the Efficient Market Hypothesis, the referent was the fundamental value (and, as Fama explained, the equalization between price and fundamental value was due to arbitrage trading). However, in his 1970 article (which is the most widely disseminated article on the Efficient Market Hypothesis), Fama replaced any reference to the fundamental value by another economic assumption, namely the hypothesis of a representative agent: all agents are supposed to react to new information in the same way, and implicitly they all have the same equilibrium price model to determine the value of the asset. From an economic viewpoint, this equilibrium price is the "fundamental value" or the "true value" (or "true density function", as Fama (1976) called it). Consequently, from an economic viewpoint, the efficient market hypothesis is directly associated with the existence of an intrinsic value implying that the distinction between the two definitions of efficiency ("tradingrule" or "mechanical" efficiency versus "value" efficiency) is not understandable. Indeed, if Fraud on the Market Theory "does not posit that there is some 'true value' of an asset other than its price" (Fischel 1989, 920), then it cannot refer to the Efficient Market Hypothesis.

This difference in the use of the fundamental value demonstrates that jurists have developed their doctrine by considering efficiency as a way to explain how markets work without any reference to the "true" economic value of assets.

\section{II.2.b) The kind of information included in prices}

The second difference between the efficient market of jurists and that of economists has to do with the kind of information included in prices. While the Efficient Market Hypothesis deals with information, jurists and financial economists have a completely different understanding of what constitutes this information.

For an economist, saying that "security prices reflect all available public information" means that only true, relevant information is reflected in prices - this is one of the origins of the term "fully" in Fama's (1970) definition. The term "fully" is very important because it supposes that investors use the right model to price the stock. This definition is directly in line with the fundamental economic idea that individuals are perfectly rational. Economic agents, being rational, filter out misrepresentation and act only on true, relevant information, which they integrate into prices; for this reason, financial markets are said to be efficient. Fama (1976) clarified this point after LeRoy (1976)'s comments: 
Thus in an efficient market the true expected return [i.e. fundamental value] on any security is equal to its equilibrium value [i.e. quoted price] [...]. In an inefficient market, on the other hand, true expected returns [i.e. fundamental value] and equilibrium expected returns [i.e. quoted price] are not necessarily identical. In setting prices at $t-1$, the market may overlook some of the information [...], or it may use the information incorrectly (Fama 1976, 144).

In an economic view of the Efficient Market Hypothesis, if an irrelevant item of information could be integrated into financial prices, then prices could not be a reflection of the fundamental value (or of the equilibrium value). Therefore, we would not have an equilibrium situation, and arbitrage would then be possible. In financial economics, a market in which false information was reflected in prices could never be efficient, by definition.

For a jurist, on the contrary, the same statement ("security prices reflect all available public information") means that all relevant information, true or false, is incorporated into the price as soon as it becomes publicly available. For instance Fisher $(2005,847)$ explained that "the essence of the efficient market hypothesis" was that "the market prices [of the stock] [...] impounded the falsity [i.e. false statement] that the defendants spoke." Misleading information will be incorporated into prices at which investors buy or sell their stocks, leading to their being defrauded. Class actions under Rule 10b-5 are brought precisely on the fact that misleading or false information can be reflected into prices.

In short, for jurists, if markets are efficient, then manipulation of prices through public false statements is possible and will impact prices while, for economists, if markets are efficient, manipulation of prices is totally impossible because only true, relevant information is incorporated into prices. As we can see, the way "information" is defined has a direct effect on the meaning we give to the notion of efficiency.

\section{II.3. Polymorphous definition of market efficiency and its consequences: current and future controversy}

Jurists and economists, then, do not conceive of the efficiency of markets in exactly the same way. The two communities use the same terminology to mean different things. Moreover, although jurists refer explicitly to financial economics to define efficiency, their use of the term runs counter to its interpretation by economists. As a result, it is reasonable to ask whether it is necessary for jurists to use financial economics to define and characterize the efficiency of financial markets.

This question lies at the heart of the debate that arose in PolyMedica between the District Court (2004) and the Court of Appeal (2005). In our perspective, a part of these debates are rooted in the polymorphous definition of efficiency 
introduced by economists in order to make more realistic the definition of the Efficient Market Hypothesis. We will explain the polymorphous definition of efficiency and analyze its consequences, focusing on these two judgments. First we will analyze the question of concept transfer between the two disciplines. We will show that the controversy in legal terms regarding the extent of the borrowing from financial economics calls into question the raison d'être for the use of efficiency in Fraud on the Market Theory. In addition to the theoretical difficulties inherent in concept transfers between disciplines (a), we will highlight the practical implications of such borrowings in terms of the extent of the possibilities for securities fraud class-action lawsuits (b).

\section{3. a) "Most" or "all and fully": the question of transfers between disciplines}

Apart from the difficulty surrounding the status of fundamental value - attested to the introduction of a double definition of market efficiency by jurists ("trading-rule" vs. "value" efficiency) - importing the Efficient Market Hypothesis into the Fraud on the Market Theory has also confronted jurists with the problem of the extent of information that stock prices are expected to reflect. In an efficient market, are prices supposed to ("fully" or otherwise) reflect "most" or "all" information? This is what the controversy about market efficiency boiled down to in PolyMedica (2004 and 2005). While the District Court's 2004 judgment called for an adaptation of the definition of an efficient market in the legal context of Fraud on the Market Theory and asserted that an efficient market "is simply one in which 'most publicly announced material statements about companies' affect stock market prices" (PolyMedica (2004), 224 F.R.D. at 41, citing Basic, 485 U.S. at 246 n. 24), the defendant appealed, alleging an error of law arising from the use of "most" in the definition of efficiency, instead of "all" and "fully": an efficient market, for all legal purposes, should really be one in which all public information is fully reflected in stock prices. The Court of Appeal would ratify the latter definition in 2005.

The question of the choice of "most" rather than "all" and "fully" to qualify the information reflected in prices in an efficient market must be seen as a consequence of the polymorphous conception of efficiency and of the manner in which concept transfers from economics into law have operated. The polymorphous conception comes from the initial project of Efficient Market Hypothesis, which was the creation of a link between three features: a mathematical model (the random walk model or the Martingale model), the concept of economic equilibrium (from the law of one price and therefore the zero profit at the equilibrium on a competitive market), and statistical results about the unpredictability of stock market prices. In this perspective, the linkage proposed by Fama leading to the definition he proposed in 1970 was however only one of many possible linkages between these three features, as subsequent literature 
would demonstrate. Precisely, the definition of the Efficient Market Hypothesis has changed depending on the emphasis placed by each author on a particular feature. For instance, Fama et al. (1969) defined an efficient market as "a market that adjusts rapidly to new information"; Jensen (1978) considered that "a market is efficient with respect to information set $\theta_{t}$ if it is impossible to make economic profit by trading on the basis of information set $\theta_{t}$; ; according to Malkiel (1992) "the market is said to be efficient with respect to some information set [...] if security prices would be unaffected by revealing that information to all participants. Moreover, efficiency with respect to an information set [...] implies that it is impossible to make economic profits by trading on the basis of [that information set]". To understand the implications of these choices for current American jurisprudence, we will now analyze one by one the justifications that have been put forward for the use of "fully" and "all", and for "most."

J.A. Lipez' view that the courts should adopt a definition of efficiency in which prices "fully" reflect "all" publicly available information relies on prior jurisprudence, in which the majority of lower courts opted for this definition taken unchanged from financial economics (and particularly from Fama 1970). Lipez concluded that it was a mistake of the District Court to depart from these precedents and to accept as efficient a market "in which market professionals generally consider most publicly announced material statements about companies, thereby affecting stock market prices." (PolyMedica 2004). At first glance, this decision seems to be motivated not by economic theory but by judicial precedent, which constitute a habitual source of law. However, it is noteworthy that the very first judgments on the issue called economists as expert witnesses to present their definition of efficiency, or cited them as authorities. ${ }^{8}$ And although in subsequent cases economic studies no longer constituted the main justification for the use of this definition - even if certain judgments continued to refer to if (see Gariety v. Grant Thornton, 368 F.3d 356 [2004] at 368; Fischel (1982)) - courts continued to refer to the early judgments, which had adopted the terms "all" and "fully" used by economists ${ }^{9}$. Therefore these terms imposed themselves on American courts, creating a jurisprudential trend invested with a wholly legal authority. By proceeding in this way, courts were nevertheless borrowing the definition of efficient market from financial economics

${ }^{8}$ In addition to LTV Securities, mentioned above, which cited the economist Van Horne directly, In re Bexar County Health Facility Development Securities Litigation (130 F.R.D. 602 [1990] at $606)$, referred to Fama (1970), as noted by Justice Lechner in PolyMedica (2004).

${ }^{9}$ See for instance, Raab v. Gen. Physics Corp. (4 F.3d 286 [1993] at 289): fraud-on-the-market presumption of reliance assumes "the market price has internalized all publicly available information"; Freeman v. Laventhol (915 F.2d 193 [1990] at 197): "the Fraud on the Market theory rests on the assumption that the price of an actively traded security in an open, well-developed, and efficient market reflects all the available information about the value of a company"; No. 84 Employer - Teamster Joint Council Pension Trust Fund v. Am. West Holding Corp. (320 F.3d 920 [2003] at 947): "in a modern and efficient securities market, the market price of a stock incorporates all available public information". 
quite literally, taking the theory as applicable "as is," with no adaptation for the judicial context ${ }^{10}$.

The 1980 In Re LTV Securities Litigation decision, one of the first explicit uses of the Efficient Market Hypothesis in Fraud on the Market Theory, provides a clear illustration of the problems posed by the literal transfer of an economics concept into legal theory. The District Court used Fama's 1970 definition directly to characterize an efficient market:

Recent economic studies tend to buttress empirically the central assumption of the Fraud on the Market theory - that the market price reflects all representations concerning the stock. Indeed, economists have now amassed sufficient empirical data to justify a present belief that widely-followed securities of larger corporations are "efficiently" priced: the market price of stocks reflects all available public information - and hence necessarily, any material misrepresentations as well. (LTV Securities, 88 F.R.D. at 144.)

However in this judgment, the economic definition of efficiency is directly followed by a - theoretically contradictory - legal conclusion ("hence necessarily, any material misrepresentations as well"). Thus, from this moment on, the problem of compatibility with the financial economists' definition of efficiency, as described previously, rears its head.

By integrating the original definition of the Efficient Market Hypothesis ("fully"), jurists imported into law a specific concept which was defined in economics. This kind of transfer is very common: many scientific concepts have been transferred from one discipline to another (equilibrium from physics to economics, value from philosophy to sociology, etc.). From this perspective, the Efficient Market Hypothesis is a "travelling" or a "nomadic" concept, defined by Stengers (1987) as a concept travelling between two (or more) fields and whose formal importation can require adaptation to make it workable in a new disciplinary context. The adaptation can be of three kinds ${ }^{11}$ : a) translation of the imported concept in order to extend its meaning to another theoretical framework; b) formal analogy developed with the imported concept in order to extend its applicability to another topic (this adaptation often implies a mathematical isomorphism between two topics); c) simplification of the imported concept in order to render it operational in the practices of other disciplines. When jurists associate the Efficient Market Hypothesis with the idea that information is "fully" reflected in the financial prices, they are simply importing from economics the concept defined by Fama (1970) without adapting it to their disciplinary context. Jurists use the Efficient Market Hypothesis as a neutral and authoritative hypothesis providing a description of financial reality, understood as an

\footnotetext{
${ }^{10}$ On this point, it is worth bearing in mind that Fama's work, and more generally that of the Chicago school research team, was widely publicized at the time of its publication and throughout the 1970s, and that these results were widely debated by economists (see Jovanovic (2008) for the debates).

${ }^{11}$ See Stengers (1987) for further information about the nomadic dimension of concepts.
} 
uncontroversial set of facts. Preferring the standard of a "full" reflection of "all" public information in prices, they appear to consider that an adaptation of the efficiency concept is not required in order for it to be operational in law.

Although this literal borrowing of economics terminology eventually prevailed, it was regularly contested. As early as in Basic (1988), the Supreme Court indicated that the courts must provide justifications for their reasoning other than the use of economic theory or hypothesis:

We need not determine by adjudication what economists and social scientists have debated through the use of sophisticated statistical analysis and the application of economic theory. For purposes of accepting the presumption of reliance in this case, we need only believe that market professionals generally consider most publicly announced material statements about companies, thereby affecting stock market prices. (Basic, 485 U.S. at 247 n. 24)

In PolyMedica (2004) Justice Keeton pointed out the difference between the efficiency required in law in order to presume reliance by plaintiffs and the efficiency defined by economists. Although he acknowledged the tendency in the jurisprudence to prefer the definition based on "fully" and "all", he stressed the fact that this jurisprudence was founded on the early judgments, which were mainly based on the literature of economics. For this reason, he did not use the literal definition of market efficiency from financial economics, preferring to base his legal definition of efficiency on "most": as already formulated in Basic, an efficient market should be conceived as one "in which market professionals generally consider most publicly announced material statements about companies, thereby affecting stock market prices." (PolyMedica (2004), 224 F.R.D. at 40, citing Basic at 246 n. 24). To justify this usage, he also stressed the importance of developing legal theory independently of the process and methodology laid down by economics:

When legal precedent is available, I follow it, not economic or academic literature. [...] Furthermore, it is plain in Basic that the Court did not want to adopt the "economic" or "academic" definition of efficient market. (PolyMedica (2004), 224 F.R.D. at 41)

Following this reasoning, a more practical use of efficiency by jurists would call for a more flexible definition in order to convey what matters for jurists (and which by itself is trivial for financial economists): that public information normally impacts price. A definition using the term "most" seems to be better crafted for this practical legal purpose. Further to the rejection of this more flexible approach to market efficiency, when the PolyMedica appeal (2005) favoured a strict "all" and "fully" definition rather than the "most" definition, certain writers and judges stressed the problem of the applicability of the economic definition of efficiency:

the PolyMedica court's new test forces judges to engage in a hyper-theoretical inquiry into whether a real-word market conforms at the margins to an academic model of an efficient market (None 2006, 2288). 
Indeed, jurists looked for a definition that could solve practical considerations, while financial economists based their definition on the necessity to make clear connections between some mathematical model (the random walk model), some empirical results, and some concept of economic equilibrium. A criterion based on "most" - unlike one based on "all" and "fully" - reflects a pragmatic adaptation of the Efficient Market Hypothesis by jurists and seemed better suited to a legal definition of efficiency. More specifically, with a conception of efficiency based on "most", jurists transform the imported concept of the efficient market in a way that extends its operationally. This less restrictive approach contrasts with the objective of theoretical foundation espoused by economists in order to better emphasize the plausibility of the effects of alleged public misrepresentation on prices. The Efficient Market Hypothesis is still mentioned, but is not used either as a theoretical constraint imposed by another field or as a neutral theory describing the financial facts. Rather, it becomes a conceptual referent, a theoretical starting point from which jurists must derive an appropriate efficiency more in line with their reality and their disciplinary context. This kind of adapted importation is often associated with an "action-based importation"12, in which the move of a notion across disciplines is governed by a need to solve complex problems. Since the imported concept is seen as a starting theoretical referent, this specific inter-disciplinarity can also generate the creation of new concepts. That is the case with the adaptation of efficiency to law with the use of the "most" criterion to define efficiency. This adaptation therefore guarantees the applicability of the Fraud on the Market Theory, even though it signals a move away from the spirit in which the economic theory of the informational efficiency of financial markets was created.

\section{II.3.b) Market efficiency and its practical outcomes: class actions and investor protection}

The difficulty of a verbatim transfer of the concept of efficient markets from one discipline to another is not merely a theoretical problem. On the contrary, whether jurists define an efficient market either as one that reflects "most" or as one that reflects "all" public information will determine the facility with which class actions can be brought in securities fraud litigation. Adopting a strict definition of efficiency requires a proof that stock prices fully reflect all public information: this situation places a much greater burden on plaintiffs before they can benefit from the presumption of reliance established by the Fraud on the Market Theory. However, efficiency in the economic sense is neither easily testable nor even easily applicable empirically implying that this notion is very difficult to prove in court. As explained, the test of the Efficient Market Hypothesis is a joint test:

${ }^{12}$ In accordance with the third kind of importation evoked in the previous section. 
whenever an empirical test rejects the hypothesis of an efficient market, we cannot know which part of this joint hypothesis (the efficiency of the market or the model used to evaluate the assets) failed to work. Beyond this problem, the empirical tests used to test this hypothesis do not provide confident results as explained hereafter.

Following Fama's (1970) categorization the literature has considered three sets of tests according to the form of the Efficient Market Hypothesis considered. Indeed, the Efficient Market Hypothesis consists of three forms depending on the set of information considered. The first one is the weak form of efficiency, where the prices reflect all past information. All past history of the stock price is already incorporated in the stock price. Hence, the investors cannot gain a superior return by studying the price charts of the financial assets. In practice, if a financial market is weak form efficient, the observation and study of past prices and returns cannot lead to identifiable price patterns that can be profitably explored. The next form of efficiency is the semi-strong form. In this form all the publically available information such as "announcements of stock splits, annual reports, new security issues, etc." are speedily incorporated into the prices (Fama 1970, 388). The speed of adjustment is particularly important, since it does not allow the fundamental analysts to gain an advantage over the other investors. That means that the fundamental analysis cannot offer superior returns to investors. The third and final form is the strong form of efficiency, which examines the informational advantage of insiders. That is the case of monopolistic access to information that the Directors or the hedge and mutual funds with access to directors may have. If the markets are strong form efficient, insiders cannot earn an abnormal return.

First of all, we must admit that the third form is quite impossible to test. The first should be the easier form to be tested. The economic literature has tested it by validating the hypothesis of the random character of stock market prices, because the Efficient Market Hypothesis is often considered as a synonym of the hypothesis of this random character. However, although the Efficient Market Hypothesis was created, among other purposes, in order to explain the random character of stock market prices, these two hypotheses are not synonymous (Jovanovic 2008, 2010). LeRoy (1973) and Lucas (1978) provided theoretical proofs that efficient markets and the martingale or random walk hypothesis are two distinct ideas: martingale or random walk is neither necessary nor sufficient for an efficient market. In a similar way, De Meyer and Saley (2003) showed that stock market prices follow a martingale even if all available information is not reflected in stock market prices. In other terms, Efficient Market Hypothesis is not empirically refutable since a test of the random character of stock prices does not imply a test of efficiency. Finally, the most convincing tests are dedicated to the semi-strong form of the hypothesis, and it is precisely the tests the courts mainly used. 
The seminal test of semi-strong form market efficiency is due to Fama, Fisher, Jensen and Roll (Fama et al. 1969), who examined the effects of stock splits on stock prices. This paper was the first to use the now classic event study methodology, which aims to measure the impact of a given firm-specific corporate event (like dividend, bonus, right issue, option listing, stock split, block trading, annual earning, etc.) on the prices of the company's securities. Typically, event studies measure the timing of security price reactions relative to the date of the event. In this perspective we try to detect if it is possible to make a profit superior to the market's performance by trading such information just before the event in question. However, it is worth emphasizing that this kind of tests focuses more on the speed with which information has an impact on the prices rather than on the degree of integration of the information integrated in prices.

Considering the difficulties for validating of the Efficient Market Hypothesis, a less literal definition of efficiency stipulating that prices must reflect "most" public information, is easier to satisfy. In this situation, given that the presumption of reliance established by Fraud on the Market Theory is itself a condition for the opening of a class action suit under rule 10b-5 (see part 1), it is obvious that the extension given to the concept of efficiency in law is quite crucial for the fate of securities fraud cases.

More than a matter of economic interpretation, the issue of legal restrictions on the possibility of bringing class action suits is a matter of policy choice regarding appropriate protection for investors. Thus, the restrictive definition of efficiency imposed by PolyMedica (2005), recently reiterated by the Supreme Court (Halliburton, 131 S. Ct. 2179 [2011]) seems indicative of a political concern by the courts to stem the proliferation of class action suits for securities fraud. That said, it is interesting to reposition the legal use of the Efficient Market Hypothesis in the context of the political debate regarding the provision of proper protection for investors. Whereas the first references to the Efficient Market Hypothesis were made in order to solidify the Fraud on the Market Theory and increase the possibilities for redress open to investors wronged by manipulation of the markets, the references to Efficient Market Hypothesis made after Basic (1988), during the 1990s and 2000s, had the opposite aim. After Basic, criticisms were voiced of what was seen as a proliferation of abusive litigation, where lawyers were said to have initiated class action suits as soon as they saw a significant drop in the stock price of a company, and it is only afterwards that they are looking for evidence of fraud (Erdlen 2011, 897). In 1995, the Congress responded to these criticisms by adopting its first major reform of securities law since the Acts of 1933 and 1934: the Private Securities Litigation Reform Act (Pub. L. No. 104-67, 109 Stat. 737 [1995], codified in scattered sections of 15 U.C.S.), which was expressly aimed at holding back class action suits (Oldham 2003). Jurists' interpretation of the concept of efficiency may still not be in line with economic theory, but it would seem to reflect their current practical concerns quite closely. 
This observation leads us to question the role played by the theory of financial economics in legal argument, and, more precisely, in the Fraud on the Market Theory. In fact, as some jurists have themselves acknowledged (Oldham 2003, 999 ) it is not actually necessary to invoke the Efficient Market Hypothesis in order to assert that a misleading statement about a company is likely to affect the price of its stock. The courts could have, for instance, held that reliance is not an element of a 10b-5 claim, but just a way to demonstrate causation (Langevoort 2009, 157-158). Moreover, correctly understood in the framework of economic theory, efficiency does not justify the contention of jurists that misleading representations are automatically reflected in stock prices. Significantly, other common-law jurisdictions - Canada, the UK and Australia ${ }^{13}$ - have not followed U.S. law on this point since they do not recognized the Fraud on the Market Theory and its reference to financial economics. For instance, in Canada the theory was rejected by several lower courts, while in Australia not only there is no statutory presumption of reliance but also no evidence of plaintiffs' attempt to introduce the fraud-on-the-market theory before the courts.

According to Duffy (2005), the unwillingness of courts outside the United States to embrace the Fraud on the Market Theory is partly due to judges' reluctance to exchange legal analysis, traditionally concerned with the righting of wrongs caused by misconduct or misleading representations. By importing economic theories in court, lawyers might limit their flexibility (see also Duffy 2009, 2011):

One of the practical implications of theory in courts is that the determination of such an effect is likely to involve economic analysis rather than legal theory, so that quantum of damages will be the subject of expert economic evidence and debate (particularly statistical material) rather than legal argument. (Duffy 2005, 637)

Nevertheless, this article has clearly shown the fragility of the US courts jurisprudence in the context of literal borrowing of terminology from economics. The fragility is all the more conspicuous, because other countries, whose legal system is based on common law, have not made use of financial economics to justify class actions based on Fraud on the Market Theory. We should however note here that American jurisprudence has been a pioneer in the development of this doctrine and the relevant case law cannot be simply ignored but it can be used as a reference point or a source of inspiration for judges internationally.

Despite the fact that the basis of the efficient-market hypothesis was at odds with both some prior case-law and some then-current economic studies (Basic, 255$56)$, as even the different measures of market efficiency were not necessarily

${ }^{13}$ For instance in Australia, each shareholder must demonstrate that they relied on the impugned conduct and that the conduct caused loss. Failure to prove causation will mean that a shareholder's claim will fail. (See Guglielmin v Trescowthick (No.2) (2005) 220 A.L.R. 515 at [73] and Johnston v McGrath (2005) 195 F.L.R. 101 at [28]-[29].) 
clear, the theory seemed to have been the right one at the right time for the purposes that the Court was attempting to address' (Dunbar and Heller 2006, 523). The (convincing) justification can be found in the practical suitability of the theory in the context of class actions and securities fraud. 'Without the ... hypothesis, there appeared to be a loophole in using the class action remedy for securities fraud' because defendants could credibly argue that individual issues of reliance would require separate trials on a class member by class member basis (Dunbar and Heller 2006, 457). In other words, Basic can only understood as a hybrid theory that brings together financial economics and civil procedure rules in an imperfect but efficient way; its prevalence for more than two decades highlights the importance that jurists attach to legal certainty even at the expense of scientific certainty. Justice White made the point that the judges in fact borrowed the authority of science and thereby give strength to their own (Basic, 253). It is no surprise that the Basic presumption has not been extended to nonsecurities cases.

\section{Conclusion}

Since the PolyMedica case, in 2005, the debate over the legal definition of market efficiency was dormant, but it was clear that we had not heard the last word yet. The Court in Halliburton II had the opportunity to revisit this hot issue and a vote of confidence was given to the Efficient Market Theory. However, the Justices did not re-examine Basic's fundamental premises and deviate from the existing caselaw; they were reluctant to overrule a 'substantive doctrine' of federal securities law, despite the fact that this doctrine, and the underlying cause of action, are 'judicial construct[s]'followed by interpretive errors in judgemade law (Halliburton II, 2411 and 2425). Irrespective of whether they showed pragmatism or respect to the Congress' intention to preserve the foundation of the fraud-on-the-market class action, the Justices reaffirmed the vitality of the Basic presumption and confirmed that the status quo in modern securities fraud action will remain the same (Coates 2015, 2).

However, there is a question that still remains open and it has not been conclusively settled. The question to know whether an efficient market refers to a situation within "all" or "most" information is "fully" (or not) integrated in stock prices is still open. On the one hand, the use of the terms "fully" and "all" is justified by a line of cases interpreting a decision given by the U.S. Supreme Court, while on the other hand, the Supreme Court itself was the first to use the term "most" and, since then, it had never expressly ruled on the legal definition of market efficiency. In this perspective, both interpretations can be justified.

The analysis in this article shows that the controversy between "most" and "all/fully", far from being a mere disagreement over terminology, reveals a gap between two understandings of market efficiency and a tension surrounding the 
manner in which jurists borrow/use concepts from economics. We have shown that, unlike the use of "fully," taken literally from the Efficient Market Hypothesis, the use of "most" reflects an adaptation by jurists of concepts drawn from financial economics. Such an adaptation of efficiency, even if it represents a move away from economic theory appears as a condition for its applicability to the legal context of Fraud on the Market Theory.

Given the fragility of the US precedent and given the conceptualization of the "efficient market" in the Fraud on the Market Theory, it is today highly likely that a pronouncement on these two terminologies ("most" or "all"/"fully") will be sought from the Supreme Court, which has hitherto left open the interpretations given by the various courts. A recent input in this debate favours the idea of replacing reliance on the efficiency of the market with 'reliance on the market price not being impacted by (and thus reflecting) misstatements and omissions' or, in other words, not being impacted by fraudulent distortion (Bebchuk and Ferrell 2014, 686). This model is based on the idea that efficiency is not a binary concept-the market is either efficient or not efficient- but that efficiency is a continuum (Bebchuk and Ferrell 2014, 689-690). At this stage it is positive that the academic debate is still on and this can influence future judicial interpretations. As Fuller argued, we should continue to 'take this skeleton in the family of the law ... from its closet and examine [it] thoroughly. After that examination we may decide what we ought to do with it' (Fuller 1930-31, 366).

\section{References}

American College of Trial Lawyers. 1972. Report and Recommandations of the Special Committee on Rule 23 of the Federal Rules of Civil Procedures. Los Angeles: American College of Trial Lawyers.

Bebchuk, Lucian A., and Allen Ferrell. 2014. "Rethinking Basic." The Business Lawyer 69 (3):671.

Bromberg, Alan R., and Lewis D. Lowenfels. 1988. Securities Fraud and Commodities Fraud, § 8.6.

Brown, James Robert. 2015. The Regulation of Corporate Disclosure. New York: Wolters Kluwer.

Carlson, Cody James. 2015. "United States of America, Supreme Court Term 2013-14 - opening comments." Public Law 165-173.

Chane-Alune, Elena. 2006. Accounting Standardization and Gouvernance Structures. In Working paper $n^{\circ}$ 0609, University of Liège.

Coates, John C. 2015. "Securities Litigation in the Roberts Court: An Early Assessment." Arizona Law Review 57:1-35.

De Meyer, Bernard, and Hadiza Moussa Saley. 2003. "On the Strategic Origin of Brownian Motion in Finance." International Journal of Game Theory 31:285-319. 
Duffy, Michael. 2005. "'Fraud on the market': judicial approaches to causation and loss from securities nondisclosure in the United States, Canada and Australia." Melbourne University Law Review 29 (3):621-664.

Duffy, Michael. 2009. "Investor Loss From Securities Non-Disclosure: A Statutory Presumption of Causation on the Canadian Model?" University of New South Wales Law Journal 32 (3):965-987.

Duffy, Michael. 2011. "Developments in United States Securities Class Actions: The Status of 'Fraud on the Market' Causation and Implication for Australia." Common Law World Review 40:345-377.

Dunbar, Frederick C., and Dana Heller. 2006. "Fraud on the Market Meets Behavioral Finance." Delaware Journal of Corporate Law 31 (2):455-532.

Erdlen, Andrew M. 2011. "Timing Is Everything: Markets, Loss, and Proof of Causation in Fraud on the Market Actions." Fordham Law Review 80:877.

Fama, Eugene F. 1970. "Efficient Capital Markets: A Review of Theory and Empirical Work." Journal of Finance 25 (2):383-417.

Fama, Eugene F. 1976. "Efficient Capital Markets: Reply." Journal of Finance 31 (1):143-145.

Fama, Eugene F., Lawrence Fisher, Michael C. Jensen, and Richard Roll. 1969. "The Adjustment of Stock Prices to New Information." International Economic Review 10 (1):1-21.

Fischel, Daniel R. 1982. "Use of Modern Finance Theory in Securities Fraud Cases Involving Actively Traded Securities." The Business Lawyer 38:120.

Fischel, Daniel R. 1989. "Symposium on the regulation of secondary trading markets: program trading, volatility, portfolio insurance, and the role of specialists and market makers: efficient capital markets, the crash, and the fraud on the market theory." Cornell Law Review 74:907-922.

Fisher, William O. 2005. "Does the efficient market theory help us do justice in a time of madness?" Emory Law Journal 54:843-978.

Fox, Justin. 2010. The myth of the rational market: a history of risk, reward, and delusion on Wall Street. Petersfield: Harriman House.

Friedman, Milton. 1953. Essays in positive economics. Chicago: The University of Chicago Press.

Fuller, Lon L. 1930-31. "Legal Fictions." Illinois Law Review 25:363, 513, 877.

Gordon, Randy D. 2013. "Fictitious fraud: economics and the presumption of reliance." International Journal of Law in Context 9 (4):506.

Hammer, Howard M., and Ronald X. Groeber. 2007. "Efficient market hypothesis and class action securities regulation." International Journal of Business Research 1:1-14.

Jensen, Michael C. 1978. "Some anomalous evidence regarding market efficiency." Journal of Financial Economics 6 (2-3):95-101.

Jovanovic, Franck. 2008. "The Construction of the Canonical History of Financial economics." History of Political Economy 40 (2):213-242. 
Jovanovic, Franck. 2010. "Efficient markets theory." In Encyclopedia of Quantitative Finance, edited by Rama Cont. Chichester (UK): John Wiley \& Sons.

Langevoort, Donald C. 2009. "Basic at twenty: rethinking fraud on the market." Wisconsin Law Review 2009 (2):151.

LeRoy, Stephen F. 1973. "Risk Aversion and the Martingale Property of Stock Prices." International Economic Review 14 (2):436-446.

LeRoy, Stephen F. 1976. "Efficient Capital Markets: Comment." Journal of Finance 31 (1):139-141.

Lucas, Robert E. 1978. "Asset Prices in an Exchange Economy." Econometrica 46 (6):1429-1445.

Mahoney, Paul G. 2009. "The Development of Securities Law in the United States." Journal of Accounting Research 47 (2):325-347.

Malkiel, Burton G. 1992. "Efficient Market Hypothesis." In The New Palgrave Dictionary of Money and Finance, edited by Peter Newman, Murray Milgate and John Eatwell. London: Macmillan.

Miburn, J. Alex. 2008. "The Relationship between Fair Value, Market Value, and Efficient Markets." Acounting Perspectives 7 (4):293-316.

Muniesa, Fabian. 2003. Des marchés comme algorithmes: sociologie de la cotation électronique à la bourse de Paris. Ph.D: Ecole Nationale Supérieures des Mines de Paris.

None. 2006. "Securities Law. Fraud-on-the-Market. First Circuit Defines an Efficient Market for Fraud-on-the-Market Purposes. In re PolyMedica Corp. Securities Litigation, 432 F.3d 1 (1st Cir. 2005)." Harvard Law Review 119 (7):2284-2291.

Oldham, Jeffrey L. 2003. "Taking 'Efficient Markets' Out of the Fraud-on-theMarket Doctrine After the Private Securities Litigation Act." Northern University Law Review 97 (2):995.

Pardo-Guerra, Juan Pablo. 2015. "Evaluation Cultures, Organizational Logics, and the Limits of Financial Regulation." University of Leicester.

Posner, Richard A. 1975. "The Economic Approach to Law." Texas Law Review $53(4): 757$.

Rubenstein, William B. 2001. "A transactional model of adjudication." Georgetown Law Journal 89 (2):371.

Schinckus, Christophe. 2008. "The Financial Simulacrum." Journal of SocioEconomics 73 (3):1076-1089.

Simon, Herbert A. 1972. "Theories of Bounded Rationality." In Decision and Organization, edited by C. B. McGuire and Roy Radner, 161-176. Amsterdam: North-Holland Publishing Compan.

Stengers, Isabelle, ed. 1987. D'une science à l'autre. Des concepts nomades. Paris: Seuil.

Van Horne, James C. 1977. Financial Management and Policy (4th ed.). Englewood Cliffs, N.J.: Prentice Hall. 
Weiss, Elliott J., and John S. Beckerman. 1995. "Let the Money Do the Monitoring: How Institutional Investors Can Reduce Agency Costs in Securities Class Actions." The Yale Law Journal 104 (8):2053-2127. 